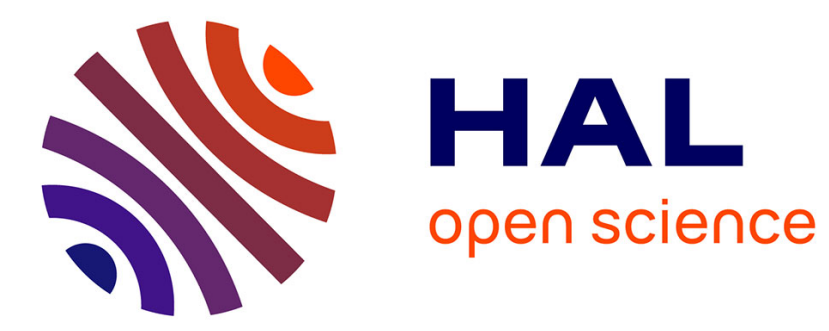

\title{
Supplément oriental et inspiration poétique
}

Claire Gallien

\section{To cite this version:}

Claire Gallien. Supplément oriental et inspiration poétique. XVII-XVIII Revue de la Société d'études anglo-américaines des XVIIe et XVIIIe siècles , 2010, L'attrait de l'Orient, 67 (1), pp.145-169. 10.3406/xvii.2010.2508 . halshs-01612005

\section{HAL Id: halshs-01612005 \\ https://shs.hal.science/halshs-01612005}

Submitted on 8 Mar 2021

HAL is a multi-disciplinary open access archive for the deposit and dissemination of scientific research documents, whether they are published or not. The documents may come from teaching and research institutions in France or abroad, or from public or private research centers.
L'archive ouverte pluridisciplinaire HAL, est destinée au dépôt et à la diffusion de documents scientifiques de niveau recherche, publiés ou non, émanant des établissements d'enseignement et de recherche français ou étrangers, des laboratoires publics ou privés. 


\section{SUPPLÉMENT ORIENTAL ET INSPIRATION POÉTIQUE}

Cet article analyse le rapport de la littérature orientale traduite au canon littéraire anglais du XVIIIe siècle en termes de «supplément ». En effet, dès le début du siècle, auteurs et essayistes anglais justifient l'intégration du style et des tropes orientaux afin de combler les manques expressifs et figuratifs de la littérature anglaise. Dans la seconde moitié du XVIIIe siècle, les auteurs et poètes appartenant aux courants sentimentaliste, gothique ou romantique se servent de ce modèle exogène comme d'un élément transgressif leur permettant de pousser les limites génériques à bout. L'Orient est donc bien plus qu'un simple décor de carton pâte : il offre à la littérature anglaise de nouveaux moyens d'expression.

This article analyzes the relationship between a corpus of Oriental texts in translation and the eighteenth-century English literary canon in terms of supplementation. Indeed, as early as the beginning of the century, English authors and essayists vindicated the introduction of Oriental tropes and style, arguing that those would make up for the expressive and figurative deficiencies of English literature. In the second half of the eighteenth century, authors and poets belonging to the sentimental, the gothic and the romantic traditions use this exogenous model as an element of transgression, allowing them to try the limits of genre. The Orient is thus much more than a pasteboard background - it provides English literature with new expressive means.

Le terme de «supplément», bien qu'emprunté au vocabulaire critique de Jacques Derrida, existe au XVIIIe siècle mais en un sens différent de celui développé par celui-ci. Si l'on prend pour point de repère le Supplément au voyage de Bougainville écrit par Diderot en 1773, on observe que le supplément avait pour fonction de donner une suite à un récit dans le but de combler les oublis, volontaires ou non, de son auteur. Ainsi, les fragments «La Harangue du vieillard» et «L'Entretien de l'aumônier et d'Orou », prétendument retirés du récit de voyage de Bougainville, constituent le corps du texte du Supplément et offrent une vision moins triomphante du voyage des « civilisés » chez les «primitifs ». Le vieillard et Orou s'expriment 
contre les progrès de la civilisation et en faveur du bonheur des peuples primitifs. Le supplément est ainsi envisagé comme une matière dissonante, qui gêne l'harmonie du texte principal, et expose ses manques, ses non-dits.

Cette notion ne s'applique pas seulement à la parole prêtée à l'indigène par opposition à celle du colonisateur. Elle définit également le rôle joué par les lettres orientales par rapport aux normes littéraires classiques en vigueur dans l'Angleterre du XVIIIe siècle. En effet, les auteurs qui se réfèrent à ces règles condamnent la poétique orientale car elle contient des éléments inadaptés, dissonants, perturbateurs pour la pureté de la langue anglaise et pour l'intégrité de son corpus en voie de constitution. Ce type de discours apparait notamment chez Clara Reeve dans The Progress of Romance (1785) et chez James Beattie dans ses Dissertations Moral and Critical (1787). Au contraire, ceux qui approuvent l'intégration de la littérature orientale, de ses thèmes et de son style, au sein d'un corpus de langue anglaise - à la même époque on peut trouver ces propos chez Robert Lowth et Joseph Moser - justifient leur position en précisant que seul l'Orient peut combler les manques expressifs et figuratifs du canon poétique anglais.

En réalité, cet argument était déjà courant dans la première moitié du XVIIIe siècle. On trouve par exemple des remarques, analysées en première partie de l'article, sur l'éloquence des Arabes et des Hébreux parmi les essayistes et auteurs de l'époque, tels Joseph Addison, Daniel Defoe et Samuel Johnson. Dans la seconde moitié du siècle, on observe rétrospectivement un glissement de l'idéal néoclassique vers d'autres formes d'écriture, comme l'écriture lyrique, sentimentale ou encore romantique. Ce contexte esthétique paraît davantage propice aux emprunts à la poésie des Orientaux. De fait, les auteurs et poètes développent alors des formes d'expression mettant en valeur les passions humaines, transposent leurs décors et personnages en Orient et imitent ce qui était perçu comme l'éloquence orientale.

Comme nous l'analyserons en deuxième partie de l'article, cette inspiration est utilisée à des fins transgressives. Elle permet d'enfreindre les normes stylistiques et génériques et de mettre en valeur l'impensable ou les non-dits. Dès lors, la littérature orientale ne vient plus seulement combler des manques constatés dans la littérature anglaise, mais permet d'aller plus loin dans certains 
contenus ou certaines formes d'expression. Notre hypothèse est de tenir l'exotisme oriental comme préalable assurant le dépassement des codes. Ce supplément oriental participe, en effet, à une logique de la surenchère sentimentale, comme dans Hartly House, Calcutta de Phebe Gibbes (1789), ou donne dans la provocation, comme dans Vathek de William Beckford (1786).

Cet argument s'inscrit dans la continuité de la réflexion menée par Homi Bhabha au sujet du phénomène d'hybridation, et par Srinivas Aravamudan et Ros Ballaster au sujet de la critique du caractère «national » du corpus littéraire anglais. J'envisage en effet d'étudier l'intertexte oriental de ces récits anglais, tout en soulignant sa part de "perturbation » et de « résistance », vocabulaire employé par Homi Bhabha pour désigner le processus d'hybridation. ${ }^{1}$

\section{Combler les manques expressifs}

Dès le début du siècle, Joseph Addison reconnaît l'ardeur des langues orientales, inspirées, comme il l'explique, du souffle divin n'oublions pas que les langues sémitiques sont les langues de la Bible - et influencées par la chaleur du climat. ${ }^{2}$ Il indique la possibilité, la nécessité même, d'intégrer la force poétique des Orientaux à la littérature anglaise :

[...] it happens very luckily, that the Hebrew Idioms run into the English Tongue with a particular Grace and Beauty. Our Language has received innumerable Elegancies and Improvements, from that Infusion of Hebraisms, which are derived to it out of the Poetical Passages in Holy Writ. They give a Force and Energy to our Expressions, warm and animate our Language, and convey our Thoughts in more ardent and intense Phrases, than any that are to be met with in our own Tongue. There is something so pathetick in this

1. «What is irremediably estranging in the presence of the hybrid $[\ldots]$ is that the difference of cultures can no longer be identified or evaluated as objects of epistemological or moral contemplation : cultural differences are not simply there to be seen or appropriated »; ou encore : «The paranoid threat of the hybrid is finally uncontainable because it breaks down the symmetry and duality of self/other, inside/outside » (Bhabha 114, 116).

2. «There is a certain Coldness and Indifference in the Phrases of our European Languages, when they are compared with the Oriental Forms of Speech » (Spectator $405,514)$. 


\section{CLAIRE GALLIEN}

kind of Diction, that it often sets the Mind in Flame, and makes our Hearts burn within us. ${ }^{3}$

Addison développe un discours emprunt de préjugés culturels au sujet des Arabes et de leur langue censée correspondre à un esprit passionné. Mais au delà de ce stéréotype, il souligne l'existence d'un métissage linguistique («runs into») entre l'anglais et l'hébreu. Il encourage par ailleurs cette union car les langues orientales apporteraient ardeur, intensité et pathétique à la langue anglaise. Elles constituent un modèle original par rapport à éloquence que David Hume retrouve chez Démosthène ou Cicéron. ${ }^{4}$

Addison développe encore l'argument prophétique dans un article du Guardian de 1713. Dans cet article, il reconnaitt une influence de l'hébreu sur les autres langues orientales : la parole sublime de Dieu est transmise aux prophètes, qui eux-mêmes, font passer les accents de cette langue poétique aux peuples sémitiques. Ainsi, l'élocution orientale révèle un esprit plus grand et relève d'un style plus énergique que les langues grecque ou latine. Elle hérite du verbe prophétique, seul capable d'exprimer des sentiments sublimes dans un style véhément. ${ }^{5}$

Daniel Defoe décrit en préface de A Continuation of Letters Written by a Turkish Spy at Paris le style des Orientaux comme suivant un registre non plus sublime mais passionnel :

[...] could I translate, or indeed could our Language express the Story with the same Vivacity, the same Spirit, and the same Energy of Words as the old exquisitely qualified Arabian delivered it, how much superior would it be to what it now appears; with what Pleasure, with what Raptures and Extasies must it be received?

\section{Ibid. . (REFERENCE?)}

4. «We are satisfi'd with our Mediocrity, because we have had no Experience of any Thing better; But the Antients had Experience of both [the rational and the sublime]; and upon Comparison, gave the Preference to that Kind [sublime eloquence] of which they have left us such applauded Models » (Hume 28-29).

5. «In Poetry it [the expression of violent motions] requires great Spirit in thought, and Energy in stile ; which we find more of in the Eastern Poetry, than either the Greek or Roman. The Great Creator, who accommodated himself to those he vouchsafed to speak to, hath put into the Mouths of his Prophets such sublime Sentiments and exalted Language, as much abash the Pride and Wit of man » (Guardian 86, 312). 
[...] but to render the sublime Flights of the incomparable Mahmut, his bright Ideas, his surprizing Turns of Wit, and Flights of Fancy ; I say, to render these exactly in our Language, is as difficult as 'tis for a painter to represent the passions, or a carver to make his Figures speak. (iii-iv)

Le passage du sublime au passionnel est significatif : ce n'est plus la langue d'un Dieu mais bien celle d'un peuple qui intéresse l'auteur. Endossant le costume du pseudo-traducteur Mahmut, Daniel Defoe répète un discours conventionnel sur la vigueur de l'idiome oriental, mais, à la différence d'Addison, il insiste sur la prétendue impossibilité à retranscrire cet idiome en anglais.

En effet, les langues orientales ont été préservées, selon l'avis des critiques et des auteurs de l'époque, dans un état primitif proche, voire identique à celui du temps des prophètes, ce qui expliquerait la diction «naturellement» vive et sublime des Orientaux mais également les difficultés rencontrées pour les assimiler à des langues «modernes ». Ainsi, la promotion de langues capables de combler le manque d'expressivité de la langue anglaise reste problématique et éminemment idéologique puisque l'Orient est maintenu au stade le moins évolué du développement des civilisations. ${ }^{6}$

Pour les auteurs de l'époque, l'éloquence, l'ardeur et le rapport au divin qu'entretiennent les langues orientales paraissent tout indiqués pour exprimer la grandeur, les passions, et le sublime. Elles s'installent donc dans un rapport de complémentarité fertile avec la langue anglaise.

La proposition sérieuse d'Addison et ironique de Defoe de laisser vibrer la puissance du souffle poétique oriental dans la langue anglaise est mise en pratique dans la deuxième partie du XVIIIe siècle alors que le classicisme est peu à peu remplacé par des formes locales de l'éloquence orientale : le pathétique lyrique et le sublime romantique.

Le poète anglais Joseph Warton élabore dès le milieu du XVIIIe siècle une défense de l'éloquence et du lyrisme. À la civilisation

6. Ainsi Edward Said explique que l'Orientalisme est un discours qui place systématiquement l'Occident dans une position supérieure face à son objet d'étude : «In quite a constant way, Orientalism depends for its strategy on this flexible positional superiority, which puts the Westerner in a whole series of possible relationships with the Orient without ever losing him the relative upper hand » (Said 7). 
urbaine des poètes de la première moitié du siècle, Warton oppose, dans The Enthusiast, publié en 1744, un retour à la nature et aux émotions «naturelles ». Il présente, en 1746, dans l'avertissement aux Odes on Various Subjects, un « manifeste » poétique lyrique :

[the author] is convinced that the fashion of moralizing in verse has been carried too far, and as he looks upon Invention and Imagination to be the chief faculties of a Poet, so he will be happy if the following Odes may be looked upon as an attempt to bring back Poetry into its right channel.

Cet avertissement annonce le rejet de la poésie morale néo-classique et définit une nouvelle forme d'écriture fondée sur l'invention et sur l'imagination. Dix ans plus tard, en 1756 dans la dédicace de son Essay on the Writings and Genius of Pope, Warton renouvelle sa condamnation à l'encontre des poètes néo-classiques, incapables selon lui d'éloquence : "The Sublime and the Pathetic are two chief nerves of all genuine poesy. What is there transcendently Sublime and Pathetic in Pope? » (x).

Le critique A. D. Harvey remarque que la publication de poésie lyrique augmente de manière significative à partir des Odes de Warton (120). En effet, Mark Akenside écrit, en 1745, Odes on Several Subjects, et William Collins propose au public, en 1746, ses Odes of Several Descriptive and Allegorical Subjects. Dans ce contexte, la poésie orientale, dite sublime et passionnelle, est présentée comme susceptible d'alimenter l'inspiration des poètes lyriques.

Dans les trois dernières décennies du XVIIIe siècle, les orientalistes britanniques publient des ouvrages savants et des traductions dans lesquels ils reprennent l'argument de la supériorité des lettres orientales dans le domaine du lyrique et du sublime. La réception de cette interprétation auprès des auteurs, des critiques et du public anglais est facilitée par une préférence accordée au sublime comme source de plaisir esthétique, notamment depuis le traité publié par Edmund Burke à ce sujet en 1757, et par l'influence du courant philosophique sur la sympathie, notamment avec Shaftesbury, Adam Smith ou encore David Hume. De même, l'orientaliste Sir William Jones remet en question la définition aristotélicienne de la perfection artistique en postulant qu'elle ne dépend pas du degré de ressemblance au réel mais de l'adéquation entre sentiment et expression : 
It seems to me that, as those parts of poetry, musick and painting, which relate to the passions, affect by sympathy, so those, which are merely descriptive, act by any kind of substitution, that is, by raising in our minds, affections, or sentiments, analogous to those, which arise in us, when the respective objects in nature are presented to our senses. («Essay II », Poems 214)

C'est précisément sur ce terrain de l'expression des passions et de la description du sublime que les poètes orientaux peuvent, selon Jones, entrer en compétition avec les poètes européens :

[...] the poets of the East must vie with those of Europe in the graces of their diction, as well as in the loveliness of their images : but we must not believe that the Arabian poetry can please only by its descriptions of beauty; since the gloomy and terrible objects, which produce the sublime, when they are aptly described are no where more common than in the Desert and Stony Arabia. (« Essay I », Poems 177)

Les orientalistes dévoilent un style et des thèmes poétiques susceptibles d'intéresser des auteurs anglais en quête d'expressivité. Cet argumentaire est aussi mis en place pour servir les intérêts propres de la cause savante en quête de légitimation.

Ils confortent enfin leurs observations en ajoutant l'argument climatique et expliquent à partir de phénomènes naturels et contemporains les élans passionnels et grandioses des Orientaux. Comme l'écrit Sir William Jones dans ce même essai sur la poésie asiatique de 1772 :

If we allow the natural objects, with which the Arabs are perpetually conversant, to be sublime, and beautiful, our next step must be, to confess that their comparisons, metaphors and allegories, are so likewise ; [...]. It is true many of the Eastern figures are common to other nations, but some of them receive a propriety from the manners of the Arabians, who dwell in the plain and woods, which would be lost, if they came from the inhabitants of cities (178).

Ce rapport de cause à effet entre milieu et langue, climat et expression, place les poètes orientaux au dessus de leurs pairs européens dans le domaine de l'expression des passions et des sentiments. De même, le langage figuratif des Orientaux pourra compléter le répertoire poétique des Anglais.

\section{Combler les manques figuratifs}




\section{CLAIRE GALLIEN}

Dans le Guardian 86, Addison perçoit et analyse le décalage entre la force du langage métaphorique des Orientaux et celui des Grecs. Il compare la description d'un cheval lancé au galop dans la version grecque d'Homère, latine de Virgile et hébraïque de l'Ancien Testament (313-14). Plus précisément, il compare le passage de Virgile :

On his right shoulder his thick mane reclin'd, / Ruffles at speed, and dances in the wind. (REFERENCE?)

et celui tiré de la Bible :

Hast thou given the horse strength ? / hast thou clothed his neck with thunder. (REFERENCE?)

Addison commente la force poétique contenue dans la métaphore de la crinière comparée à la foudre :

I cannot but particularly observe, that whereas the Classical Poets chiefly endeavour to paint the outward Figure, Lineaments, and Motions ; the Sacred Poet makes all the Beauties to flow from an inward Principle in the Creature he describes ; and thereby gives great Spirit and Vivacity to his Description. [...] 'Has thou clothed his neck with thunder?' Homer and Virgil mention nothing about the Neck of the Horse, but his Mane : The Sacred Author, by the bold Figure of Thunder, not only expresses the shaking of that remarkable Beauty in the Horse ; and the Flakes of Hair which naturally suggest the Idea of Lightning ; but likewise the violent Agitation and Force of the Neck. (REFERENCE?)

L'auteur apprécie la langue poétique orientale pour sa capacité à voir au delà des formes du monde sensible. Par l'usage de la métaphore, le poète oriental découvre des rapports analogiques - ici entre la crinière du cheval et la foudre - et renouvelle notre perception du monde.

Le système tropologique oriental correspond à la définition de l'analogie donnée par Aristote dans la Poétique (1457b). Malgré cette conformité, l'intégration de ces analogies «rares», parce qu'étrangères, risque d'échouer à cause de difficultés de compréhension. De même que le style oriental est décrié au début du siècle pour sa véhémence, le système analogique des Orientaux est parfois rejeté car ses images sont jugées «barbares». En effet, comme le précise Addison dans Spectator 421, la beauté des comparaisons, métaphores et allégories dépend entièrement du rapport juste et évident avec l'idée ou la chose qu'elles représentent : «[that] they may please the Imagination, the Likeness ought to be 
very exact, or very agreeable, as we love to see a Picture where the Resemblance is just, or the Posture and Air graceful » (578).

La métaphore doit être explicite pour être belle, et le lecteur capable de percevoir instantanément le lien entre l'idée et sa représentation figurée. En effet, en changeant de milieu, l'homme change de système de représentation. Les tropismes ne sont pas entièrement interchangeables et l'intrusion peut être déclarée impropre. Le caractère abstrus du langage figuré des Orientaux le condamne à demeurer hors du système tropologique anglais.

Les orientalistes travaillent donc à contre-courant et tentent de faire admettre auprès du public anglais que le tropisme oriental n'est pas synonyme de barbarie ou d'obscurantisme, et qu'il peut même participer au renouvellement d'un patrimoine littéraire obsolète. Ils mettent en place divers procédés argumentatifs visant, dans un premier temps, la compréhension du système figuratif oriental et, dans un second temps, le possible remplacement du système analogique anglais par celui venu d'Orient.

Ils soulignent d'abord «l'élégance » de la diction des Arabes, des Persans et des Indiens. ${ }^{7}$ Ils encouragent également leurs lecteurs à changer de point de vue et de perspective pour pouvoir juger correctement des images orientales. Ainsi, Robert Lowth met le critique en garde contre le jugement anachronique de la poésie sublime des Orientaux :

Not only the antiquity of these writings forms a principal obstruction in many respects ; but the manner of living, of speaking, of thinking, which prevailed in those times, will be found altogether different from our customs and habits. There is therefore great danger, lest viewing them from an improper situation, and rashly estimating all things by our own standard, we form an erroneous judgment. [...] in one word we must endeavour as much as possible to read Hebrew as the Hebrews would have read it. (113)

L'antiquité des écrits, l'étrangeté des mœurs qui sont décrites dans le texte peuvent tromper un jugement trop rapide. Seule une bonne connaissance de la géographie, de l'histoire et de la culture des peuples orientaux garantit une véritable compréhension de leur langage et images poétiques. Le lecteur doit se mettre à la place de

7. Voir l'essai de Sir William Jones, « On the Musical Modes » (74), et celui de John Richardson, «A Dissertation on the Languages, Literature and Manners of Eastern Nations » (vii). 
l'autre pour apprécier, comme l'autre, la beauté et la force des vers déclamés, plutôt que de mettre la parole orientale au diapason d'un canon esthétique anglais. ${ }^{8}$

Enfin, les orientalistes dévoilent la logique cachée du système analogique oriental au moyen d'explications et de commentaires. ${ }^{9}$ «L'Hymne à Camdéo », souvent cité comme source d'inspiration pour le poète romantique Southey dans Curse to Kehama, est traduit par Sir William Jones et publié en 1785. Jones introduit l'hymne par une description du dieu Camdéo :

The Hindu God, to whom the following poem is addressed appears evidently the same with the Grecian Eros, and the Roman Cupido ; but the Indian description of his person and arms, his family, attendants, and attributes, has new peculiar beauties. (1)

Il identifie le dieu Kama au moyen d'un parallèle avec le panthéon gréco-romain, connu de ses lecteurs, et encourage ces derniers à s'intéresser au récit de Camdéo car ils y glaneront des descriptions plaisantes et nouvelles. La mythologie hindoue n'est pas un simple exotisme de façade qui répèterait des lieux communs en modifiant seulement les noms. Elle complète la littérature européenne au moyen de figures nouvelles. À ce sujet, Jone écrit : « His bow of sugar-cane or flowers, with a string of bees, and his five arrows, each pointed with an Indian blossom of a healing quality, are allegories equally new and beautiful » (2).

De même, le mythe indien fournit un répertoire thématique nouveau associé au dieu Amour. Jones rend ce répertoire intelligible au moyen du commentaire initial :

8. Cet argument est particulièrement novateur par rapport au traitement de l'orient littéraire à l'époque. En effet, depuis l'adaptation littéraire des Mille et une nuits par Antoine Galland au début du XVIIIe siècle, traducteurs et auteurs de contes pseudo-orientaux optent davantage pour des versions retravaillées et accordées au goût du public français ou anglais.

9. Il important de faire référence ici aux travaux de Michael S. Dodson sur la traduction en contexte colonial. Le critique identifie deux courants dans la pratique de la traduction : le courant de l'« autochtonisation » et celui de «l'allogénisation ». Dans le premier cas, le traducteur transforme et adapte le texte source pour le rendre familier des lecteurs auxquels il s'adresse. Dans le second, il maintient volontairement la part d'étrangeté du texte (Dodson 810). Néanmoins, «l'allogénisation » n'est pas seulement un moyen qu'utilisent les orientalistes pour maintenir le texte étranger à un stade primitif. Au contraire, il est généralement commenté et expliqué au lecteur pour lui permettre de se l'approprier et ainsi se familiariser avec les œuvres issues de la littérature indienne. 
His [Camdeo's] favourite place of resort is a large tract of country round AGRA, and principally the plains of Matra, where KRISHEN also and the nine GOPTA, who are clearly the Apollo and Muses of the Greeks, usually spend the night with musick and dance. [...] The seventh stanza alludes to the bold attempt of this deity to wound the God Mahadeo, for which he was punished by a flame consuming his corporeal nature and reducing him to a mental essence ; and hence his chief dominion is over the minds of mortals, or such deities as he is permitted to subdue. (2)

Puis, il utilise ces thèmes comme matériau poétique original dans l'hymne :

Can men resist thy pow'r, when Krishen yields,

Krishen, who still in Matra's holy fields

Tunes harps immortal, and to strains divine

Dances by moon-light with the Gopia nine?

But, when thy daring arm untam'd

At Mahadeo a loveshaft aim'd,

Heav'n shook, and smit with stony wonder,

Told his deep dread in bursts of thunder,

Whilst on thy beauteous limbs an azure fire

Blaz'd forth, which never must expire. (6)

L'orientaliste explique les allégories des Hindous aux lecteurs anglais au moyen de récritures annotées de leurs textes sacrés. Les critiques littéraires, écrivant par exemple dans la Monthly Review, apprécient ce renouvellement figuratif : « [it] will equally delight the admirers of genuine and elegant poetry, and lovers of Eastern allegory » (357). Les poètes romantiques de la génération de Byron, Shelley et Southey trouveront dans ce répertoire tropologique oriental une nouvelle source d'inspiration. ${ }^{10}$

Les orientalistes éclairent le langage figuratif des Orientaux, le rendent intelligible, non en l'adaptant mais en l'expliquant. Leur premier objectif, qui est d'assurer la compréhension des tropes orientaux, est accompagné d'un second qui vise à créer un corpus figuratif supplémentaire et disponible pour les auteurs de langue anglaise.

La démarche des orientalistes s'inscrit donc plus largement dans un « déni de récriture »- soit le refus de réemployer des thèmes, des

10. V. de Sola Pinto (693-94) se réfère à la dette des poètes romantiques à l'égard de Jones qui leur aurait fourni un langage figuratif nouveau. 
formes ou des images éculés - typique de l'esthétique romantique. ${ }^{11}$ Sir William Jones montre aux auteurs anglais comment sortir de l'impasse de la répétition et comment créer, enfin, du nouveau à partir d'images empruntées aux Orientaux. Il l'explique ainsi :

I cannot but think that our European poetry has subsisted too long on the perpetual repetition of the same images, and incessant allusions to the same fables : and it has been my endeavour for several years to incalculate this truth, That if the principal writings of the Asiaticks, which are reposited in our publick libraries, were printed with the usual advantage of notes and illustrations, and if the languages of the Eastern nations were studied in our places of education [...] we should have a more extensive insight into the history of the human mind, we should be furnished with a new set of images and similitudes, and a number of excellent compositions would be brought to light, which future scholars might explain, and future poets might imitate. («Essay I », Poems 198-99)

À la répétition perpétuelle des mêmes images, Sir William Jones propose de substituer le langage métaphorique des Orientaux. L'orientaliste, convaincu de l'adage selon lequel trop de répétitions tuent la répétition, annonce l'issue éventuelle d'une « crise » littéraire au moyen d'un détour par l'Orient. Ainsi, la plupart de ses traductions regorgent de termes empruntés au vocabulaire oriental. Il prévoit de cette façon l'intégration d'un nouveau lexique au sein du corpus littéraire de langue anglaise. Sa démarche sert de modèle aux poètes romantiques et aux critiques anglais qui cherchent en Orient la vigueur nécessaire à un élan poétique plus intense. ${ }^{12}$

11. Didier Coste envisage l'esthétique romantique sous l'angle du déni de récriture et l'oppose à l'esthétique classique de l'imitation : «From the early modern period to the Enlightenment, vernacular prose as well as verse built up a capital of appropriated, recovered or adapted, evolutionary thematic materials, structures and techniques. [...] We could then consider the long Romantic period (including the avant-gardes of the early 20th century) as that of the denial of rewriting, sometimes blind, sometimes in ill faith, rather than a time when rewriting was not common practice » (16).

12. Voir à ce sujet deux articles de Garland Cannon, «Sir William Jones and Literary Orientalism » et «Sir William Jones and the New Pluralism over Languages and Cultures ». Dans ce dernier article, Cannon écrit : "Though he never directly stated that English was inadequate and lacked certain 'inkhorn terms' from Arabic and Persian, his constant introduction of these words demonstrates that he considered the transfer of such items important in any serious reformation of English poesy, in anticipating the coming Romanticism, especially its Oriental aspects » (134). 
La littérature orientale joue un rôle de substitut au modèle classique par le biais de formes d'expression et d'images poétiques nouvelles. Sa qualité de littérature exotique lui permet aussi de figurer au premier plan d'une esthétique transgressive.

\section{Transgresser pour créer}

\section{Surenchère fabuleuse}

L'Orient permet aux auteurs anglais de créer une surenchère fabuleuse. En effet, Addison et les autres auteurs du Spectator utilisent souvent des fables pour illustrer les idées présentes dans leurs articles. Parmi ces récits fabuleux, ils empruntent parfois à la littérature orientale. On remarque néanmoins, qu'à la différence des autres types de fables (animalière, philosophique...), le conte oriental les autorise à surenchérir dans l'invraisemblance et à transgresser les cadres du bon goût. ${ }^{13}$ Ce processus a lieu au moyen de déplacements narratifs : l'auteur laisse la parole à un narrateur oriental qui prend en charge le récit et ses écarts.

Cette technique est, par exemple, mise en place dans le numéro 578 du Spectator écrit par Eustace Budgell, cousin de Joseph Addison, et consacré à une réflexion sur le concept d'identité. L'auteur sélectionne alors un conte persan pour illustrer ce concept. Un derviche perfide enseigne au roi Fadlallah comment l'âme peut

13. Le conte oriental, par ses excès fabuleux, reste jusqu'à la fin du siècle l'opposé du «bon goût » littéraire. James Beattie raille les invraisemblances des Mille et une nuits, signes de l'immaturité littéraire des Orientaux : "Every thing is carried on by enchantment and prodigy; by fairies, and genii, and demons, and wooden horses, which, on turning a peg, fly through the air with inconceivable swiftness » (238-39). Clara Reeve condamne le même excès d'invraisemblance dans son essai The Progress of Romance, publié deux ans après les Dissertations de Beattie. Elle écrit au sujet des Nuits : «[they are] all wild and extravagant to the highest degree ; they are indeed so far out of the bounds of Nature and probability that it is difficult to judge of them by rules drawn from these sources » (58). Reeve décrit la peur d'une écriture déréglée. Richard Hole stigmatise les contes orientaux pour leur immaturité dans l'ouvrage même qu'il consacre à la défense de leur statut esthétique : «the sedate and philosophical turn from them with contempt : the gay and volatile laugh at their seeming absurdities : those of an elegant and correct taste are disgusted with their grotesque figures and fantastic imagery; and however we may be occasionally amused by their wild and diversified incidents, they are seldom thoroughly relished but by children, or by men whose imagination is complimented at the expense of their judgement » (8). La littérature orientale est condamnée par ses invraisemblances à demeurer une littérature infantile. 
quitter le corps et animer un cadavre. Le roi, impatient de tester son nouveau pouvoir, quitte son corps pour réanimer celui de la biche qu'il a tuée pendant sa partie de chasse. Le derviche prend alors l'apparence du roi et va séduire la reine Zemroude sous le regard impuissant de ce dernier. Fadlallah quitte successivement le corps de la biche et s'incarne dans celui du rossignol puis dans celui d'un chien. La reine Zemroude, affligée de la perte de son rossignol, obtient du roi-derviche l'assurance que son rossignol retrouvera la vie. Le derviche quitte le corps du roi pour prendre celui du rossignol, le roi quitte le corps du chien pour reprendre son apparence de roi et tord le cou au rossignol-derviche.

Le surnaturel tourne au grotesque par la description de métempsychoses en série. Ces surenchères de la fable éloignent le conte oriental du discours philosophique. Sans renoncer à son rôle premier d'illustration du concept d'identité, le conte développe une fonction propre qui prend le pas sur la fonction première. Son rôle n'est pas simplement ou pas uniquement d'illustrer la réflexion qui précède mais avant tout de divertir et de surprendre les lecteurs par le tour grotesque que prennent les événements. L'invraisemblance du récit retranscrit par Budgell est excessive, bousculant les limites du bon goût littéraire anglais et provoquant l'imaginaire du lecteur. Une esthétique de l'écart exotique permet de passer sans transition d'une pensée sobre à son illustration « extravagante ». ${ }^{14}$

Le texte oriental permet cet excès de la fabula en direction du surnaturel. De même, un correspondant du Spectator relate une vision provoquée par la lecture d'un passage de la vie de Mahomet qu'il juge extravagant. La rencontre mystique de Mahomet avec l'ange Gabriel, tirée de la Vie du prophète, est transformée en un examen grotesque du cœur de ses proches afin d'y déceler les marques du vice. La surenchère grotesque, où le cœur des proches, placés dans des bocaux, sont décrits avec précision, produit un effet de parodie du fantastique. L'auteur jouit, au moyen des lettres orientales, et, plus précisément, en parodiant cette littérature, d'une capacité de pousser la littérature et la lecture « à bout ».

14. L'adjectif est employé par Addison pour se référer aux contes du fabuliste oriental Pilpay : «there is a pretty Instance of this Nature in a Turkish Tale, which I do not like the worse for that little Oriental Extravagance which is mixed with it » (Spectator 512). 


\section{Surenchère gothique}

La surenchère orientale ne concerne pas seulement le fabuleux mais s'applique également à l'esthétique gothique. Le conte pseudooriental Vathek est un bon exemple des dépassements permis par l'imaginaire oriental. L'auteur de ce conte, William Beckford, donne à ses personnages, au décor et aux péripéties les tours d'un récit gothique. En effet, le calife Vathek est décrit par le narrateur comme une figure monstrueuse, puisqu'elle est à la fois naturelle et contrenature: "His figure was pleasing and majestick; but when he was angry, one of his eyes became so terrible, that no person could behold it » (1). Il possède également une sensualité exacerbée, à la limite entre raffinement et débauche. Il a ainsi fait construire cinq palais dédiés aux plaisirs des sens. Enfin, l'inclination faustienne du calife anime chez lui un désir insatiable de connaissance qui l'entraîne de la maîtrise de la nature à la compréhension du divin.

Le Giaour (Satan), déguisé au début du conte en voyageur indien, tente le calife, sa compagne Nouronihar et sa mère Carathis. Il exacerbe leurs désirs et les attire en Enfer. Le lecteur est, quant à lui, entraîné dans une interprétation fétichiste du personnage, entretenant avec ce dernier un rapport de fascination-répulsion: attrait pour la démesure, mais peur de son caractère maléfique.

Beckford se sert aussi de l'Orient pour développer une écriture sublime. Dans sa description de l'Enfer et des fantômes qui le peuplent, il associe fabuleux oriental représenté par la cohorte des génies, horreur infernale et véhémence du style :

Every portal opened at their [Vathek's and Nouronihar's] approach. The Dives fell prostrate before them. Every reservoir of riches was disclosed to their view; but they no longer felt the incentives of curiosity, of pride, or avarice. With like apathy they heard the chorus of Genii, and saw the stately banquets prepared to regale them. They went wandering on, from chamber to chamber; hall to hall, and gallery, to gallery; all without bounds or limits; all distinguishable by the same louring [sic] gloom ; all adorned with the same awful grandeur ; all traversed by persons in search of repose and consolation ; but, who sought them in vain ; for every one carried within him a heart tormented in flames. Shunned by these various guilt, they withdrew from them to wait, in direful suspense, the moment which should render them to each other the like objects of terror. (201-02) 


\section{CLAIRE GALLIEN}

Vathek et sa compagne Nouronihar pénètrent en Enfer et y attendent le supplice éternel. L'arrivée de deux personnages est décrite selon le modèle liminaire des récits d'initiation, mais ici le franchissement du portail ne signale pas le passage à un stade supérieur de l'existence. Il est au contraire une régression. Ces lieux sont peuplés d'êtres étranges, les div, démons de la mythologie perse, et les génies du folklore arabe.

La présence du surnaturel oriental opère, comme Joseph Moser l'explique dans la préface de son propre conte pseudo-oriental, une surenchère du sublime. ${ }^{15}$ Dans le cas de Vathek, cette introduction ajoute une dimension blasphématoire au sublime. Elle marque le renversement des rapports entre l'humain et le divin, le bénéfique et le maléfique. Les démons se prosternent devant le calife et Nouronihar: l'humiliation et le respect sont adressés à des êtres maudits.

L'éloquence du style renforce aussi la grandeur de la description et rappelle l'effroi des personnages. La répétition anaphorique du quantitatif <every> marque la multiplication des objets et souligne, par contraste, le paradoxe infernal vécu par les protagonistes, entourés de richesses mais ne ressentant plus aucun désir. Le rythme ternaire introduit par les prépositions <from... to...> donne à leur progression une allure majestueuse, embellie par l'équilibre de la répétition d'un même terme : <from chamber to chamber, from hall to hall and gallery to gallery>. Cette répétition démultiplie l'espace en même temps qu'elle l'élargit dans le passage de la chambre à la salle puis à la galerie. Les prépositions <from... to...> indiquent le passage d'un espace vers un autre espace et, pourtant, les personnages et les lecteurs ne découvrent que la répétition du même, propre à susciter un sentiment d'effroi face à l'indistinct. ${ }^{16}$

15. «The readers and critics, who have honoured the Turkish Tales with their approbation, will please to observe, that in the following volumes, I have, in consequence of the promise made in the preface of that work, with a little more confidence, ventured to submit another production of the same nature to their inspection. [...] They will see that I have ascended one step higher in the regions of fancy ; that I have made an effort towards the sublime, by the introduction of a supernatural being » (i-ii).

16. La peur de l'indistinct correspond à la peur provoquée par la perte de tout repère, l'effondrement de la culture et le retour au chaos. Dans Le Bouc Émissaire, René Girard explique que la crise d'une société se manifeste par le passage du différencié à l'indifférencié, de l'échange différé dans le temps, principe fondateur de 
Le rythme à quatre temps introduit par l'adverbe <all> renforce l'impression de majesté. Les espaces ne sont plus distingués les uns par rapport aux autres mais regroupés autour de facteurs communs. Leurs traits distinctifs sont effacés - chaque reprise anaphorique du terme <all> renforçant l'omniprésence de l'indistinct - au profit de l'illimité, des ténèbres, de la grandeur effrayante et du sentiment partagé de culpabilité. Les personnages sont placés dans une situation ambivalente où leurs mouvements de retrait n'empêchent pas l'inexorable avancée du destin. Le suspense qui les effraie est ressenti par les lecteurs, eux aussi en attente d'une résolution. Le mécanisme de la sympathie imaginaire rapproche les lecteurs des personnages, tout en préservant une distance protectrice entre eux. L'empathie ne devient jamais substitution et à cette condition seule le spectateur peut apprécier le sublime.

Mais dans Vathek, Beckford pousse le fabuleux et le sublime oriental à bout, au point de les renverser et de produire des situations grotesques. Prenons pour exemple l'épisode où Vathek s'enfuit du palais et trouve refuge dans une montagne décrite par le narrateur comme le paradis terrestre. L'émerveillement du lecteur est sollicité par les descriptions détaillées des plantes et des fleurs qui embellissent le paysage. Le narrateur conclut ce passage en mentionnant quatre fontaines qui offrent un dernier parallèle saisissant avec les quatre fleuves du paradis :

Four Fountains, not less clear than deep, and so abundant as to slake the thirst of ten armies, seemed purposely placed here, to make the scene more resemble the garden of Eden; which was watered by four sacred rivers. (24)

La majesté du paysage est dégradée par la présence grotesque du calife :

To this mountain Vathek was sometimes brought, for the sake of breathing a purer air ; and, especially, to drink at will of the Four Fountains. [...] But it frequently happened, that his avidity exceeded his zeal, insomuch, that he would prostrate himself upon the ground to lap the water. (24-25)

toute culture, à la confusion. La perte de la différence, associée chez Beckford, à la perte du désir, en tant que préférence, même fugitive, accordée à un objet plutôt qu'à un autre, provoque l'effroi, car elle est le signe de la chute des derniers remparts de la culture, n'opposant plus aucune barrière au chaos infernal. 


\section{CLAIRE GALLIEN}

Le narrateur crée un décalage grotesque grâce à la collocation d'une attitude de dévotion («prostrate himself upon the ground») et d'un mouvement animal («to lap the water»). Le même type de dissonance est perceptible au sujet de l'énigmatique voyageur indien. Son visage inspire un sentiment d'effroi à tous ceux qui le croisent : son rire est un hurlement et son sourire une grimace, preuve de son origine démoniaque. Sa présence angoissante entre les murs du palais provoque l'affolement des résidents lorsqu'il se transforme en balle lancée à travers les pièces et bousculant tout sur son passage. La description de cette scène de panique prend, néanmoins, des allures carnavalesques :

The stranger afforded them no small entertainment ; for, being both short and plump, he collected himself into a ball, and rolled round on all sides, at the blows of his assailants [...]. The women of the harem, amazed at the uproar, flew to their blinds to discover the cause ; but, no sooner did they catch a glimpse of the ball, than, feeling themselves unable to refrain, they broke from the clutches of their eunuchs, who, to stop their flights, pinched them till they bled ; but, in vain : whilst themselves, though trembling with terror at the escape of their charge, were as incapable of resisting the attraction. (32-33)

Les habitants du harem vivent une expérience terrifiante mais le narrateur bloque l'empathie des lecteurs par le ridicule. Le voyageur terrifiant ne semble utiliser aucun pouvoir magique pour se transformer en balle. Sa taille et sa corpulence suffisent.

L'efficacité de son pouvoir enchanteur sur les femmes du harem est, quant à lui, énigmatique. Le narrateur n'exploite pas cette énigme pour susciter l'effroi du lecteur. La scène tourne même au grotesque lorsque les eunuques, pris de court par la panique des femmes, se mettent à les pincer jusqu'au sang pour les empêcher de s'échapper. Les gardiens finissent par succomber à l'attraction de l'être maléfique et ne peuvent plus tenir leur rôle de protecteurs.

Le sublime et le gothique sont à la fois amplifiés par la référence à l'Orient et déstabilisés. Les stéréotypes véhiculés sur la langue orientale, décrite comme véhémente et hyperbolique, et l'esprit passionnel des Orientaux, sont mis à profit dans l'expression du sublime. Beckford joue de ces stéréotypes, se permet des écarts avec l'exotique, au point de faire basculer le sublime dans le grotesque. Ces dissonances témoignent d'une volonté de transgresser les prescriptions génériques. 


\section{Surenchère sentimentale}

Le topos oriental est aussi envisagé par les auteurs de la seconde moitié du siècle comme un dépassement de l'écriture sentimentale. Lynn Festa, dans son ouvrage intitulé Sentimental Figures of Empire, explique que l'écriture sentimentale, et non épique, constitue un mode d'expression choisi de manière quasi systématique pour décrire le rapport de la métropole à la colonie ou du colonisateur au colonisé. Elle met en valeur la collusion entre expression sentimentale et discours colonial. L'humanisme latent du discours sentimental implique une distinction préalable et sécurisante entre les sujets et les objets sentimentaux et permet de justifier l'entreprise impériale, exprimée en termes de bienfaisance, de générosité et de pitié. ${ }^{17}$

L'Orient, et plus précisément l'expérience coloniale d'une jeune femme en Inde, constitue, comme le démontre la narratrice du roman épistolaire Hartly House, Calcutta, un terrain propice à son éducation sentimentale. En effet, le culte hindouiste représente pour la narratrice à la fois le berceau et le point d'aboutissement de la morale sentimentale. Il correspond à une doctrine sentimentale parfaite, plus complète que le sentimentalisme anglais, car elle ne s'arrête à la sympathie pour le genre humain mais implique un respect pour tout être vivant.

Sophia Goldborne relate pour sa correspondante la rencontre avec un brahmane qui devient son tuteur. Elle remarque ses qualités intellectuelles, mais elle ne tarde pas à avouer à son amie son désir pour le jeune indien : «I would have given more than I shall mention to have known my Bramin had distinguished me from the rest of the company ; but was not so happy » (272). Sophia n'en dit pas plus long sur la naissance d'un désir scandaleux pour un homme d'une «race» différente. Cinq lettres plus tard, elle explique la

17. «By designating certain kinds of figures as worthy of emotional expenditure and structuring the circulation of affect between subjects and objects of feeling, the sentimental mode allowed readers to identify with and feel for the plight of other people while upholding distinctive cultural and personal identities; it thus consolidated a sense of metropolitan community grounded in the selective recognition of the humanity of other populations. Sentimental depictions of colonial encounters refashioned conquest into commerce and converted scenes of violence and exploitation into occasions for benevolence and pity » (Festa 2). 
conversation ambiguë qu'elle a eue avec son brahmane au sujet de la transmigration des âmes :

I asked my Bramin, on his making me his congratulation on my recovery, to tell me what transmigrations (according to the best of his opinions) would have been my fate, if I had died, as was expected, in my illness.- He smiled - blushed, I think - and gave me to understand, that I should never have lost the power of pleasing because I have not exercised that power unworthily in my human shape.- 'I suppose then,' said I, 'I may conclude, from your complaisance, that I should have figured away as a cockatoo, or sung myself into somebody's good graces in the form of a minho or, perhaps, have been honoured with the person (if I may so call it) of a Bramine kite.' - He shook his head, and made me believe it very probable, that, as I had so long been worshipped as a lady, I might be favoured with divine honours, when I commenced one of the feathered race [...]. I, in the conclusion, however, told him, that unless I lost my consciousness with my form, I should be happy to know myself under his protection - for I think so highly of you, said I, that you are deemed by me, one of the kindest of the kind people to which you belong. He promised me to observe every lovely creature, (that was his word) if he survived me, in order to accomplish my wish, and render himself happy by being useful to me. (72)

L'épistolière décrit dans cette lettre une idylle amoureuse naissante avec le brahmane. La jeune femme s'adresse à son professeur sur le ton de la plaisanterie et lui demande qu'elle aurait été l'animal de sa réincarnation. Elle provoque une réponse complice de la part de son interlocuteur qui la prend au mot et profite de l'insinuation pour glisser des paroles douces à l'oreille de l'aimée. La narratrice présente à sa correspondante et aux lecteurs une scène d'intimité où seuls un homme et une femme sont présents.

L'audace de la jeune femme ne concerne pas seulement son comportement, il affecte aussi son discours, puisqu'elle s'adresse au brahmane par sous-entendus. La scène est décrite du point de vue de Sophia et seules ses paroles sont retranscrites au style direct. Elle manipule le jeune homme, qu'elle encourage au jeu érotique de la révélation voilée, et manœuvre l'interprétation de ses lecteurs. La narratrice dessaisit le brahmane de sa parole et le dépouille de ses sentiments pour les retranscrire elle-même auprès de ses lecteurs. Elle ne transmet pas seulement ce qu'elle voit mais aussi ce qu'elle croit voir, ce qu'elle devine, et attribue au brahmane des sentiments qu'il 
lui appartient de maintenir cachés. Contrairement aux hésitations de son interlocuteur, Sophia offre une représentation suffisamment claire pour diriger la compréhension de ses lecteurs : «He smiled - blushed, I think », précise-t-elle.

L'épistolière ne décrit rien de plus qu'une relation platonique entre deux êtres doués de sentiments. Néanmoins sa description apparaît au lecteur comme une interprétation organisée d'après la liste de marqueurs, tels que «I think», «gave me to understand», et «made me believe». L'écriture lui permet de témoigner, par allusions, d'une relation interdite. La romance sentimentale entre une jeune Anglaise et son brahmane contient une charge transgressive trop importante pour pouvoir être traitée directement et la narratrice préfère user de litotes.

À ce stade du récit, la liaison amoureuse semble, en effet, déjà entamée. La parenthèse finale «(that was his word) » rappelle que le discours précédent est de l'ordre de l'interprétation et ne correspond pas à une transcription verbatim des propos du brahmane. Elle permet à la narratrice de souligner le terme employé par le jeune homme et de confirmer son interprétation de la scène comme déclaration amoureuse.

L'élément oriental a donc pour fonction de surenchérir sur le discours sentimental anglais : il expose une doctrine sentimentaliste plus parfaite et permet d'exprimer à distance une passion transgressive. L'Inde apparaît comme un modèle sentimental à l'épreuve duquel sont révélées l'hypocrisie et la répression sousjacente au sentimentalisme anglais. Le sentimentalisme oriental n'entre donc pas systématiquement en consonance avec l'idéologie coloniale, comme le laisse entendre Lynn Festa dans son ouvrage, Sentimental Figures of Empire. Il agit aussi comme un défi lancé aux manques et aux manquements esthétiques et moraux du sentimentalisme anglais.

Phebe Gibbes clôt son roman sur l'épisode dramatique d'un viol perpétré par un militaire anglais sur une jeune indienne. La scène du viol est entièrement décrite et représente par métonymie la violence des rapports entre l'Inde et la Grande-Bretagne. L'analogie réduit certes le sous-continent au rang de victime impuissante, mais exprime surtout une condamnation sans appel contre la violence coloniale : «I now rejoice, more than ever, that I am about to leave a country, where fiend-like acts are, I fear, much oftener perpetrated than detected ; 
for, the grave complains not, and gold can unnerve the arm of justice» (158). Les voix féminines de Sophia Goldborne ou de la jeune indienne entendue lors du procès intenté contre son violeur témoignent de la brutalité de la colonisation. Elles font tomber le masque de la virilité coloniale et dévoilent un comportement monstrueux, tout comme la voix de la sentimentalité orientale révèle les faux-semblants et les insuffisances de la sentimentalité anglaise.

Poser la question de l'Orient en termes d'authenticité, d'inauthenticité ou encore de "décor» paraît insuffisant pour comprendre le rôle du paradigme oriental dans les lettres anglaises du XVIIIe siècle. C'est pourtant ce à quoi se sont attachés certains spécialistes de la question, tels Arthur Weitzman au sujet du conte philosophique pseudo-oriental Rasselas ou Cécile Révauger dans «Le Conte oriental à l'épreuve des Lumières en Angleterre ».

L'intégration d'un corpus oriental traduit pour un public européen ne sert pas seulement à changer de décor et à masquer des intentions polémiques sous des costumes orientaux. Conçue à partir des stéréotypes véhiculés à l'époque au sujet de l'éloquence des langues orientales et de l'esprit enflammé de ses peuples, la référence à l'Orient offre aux modes lyrique, sentimental et sublime des moyens d'expression.

Ainsi, bien avant l'usage de l'Orient par les poètes romantiques anglais, le paradigme oriental joue un rôle actif dans la constitution du canon littéraire. Cependant, sa nature exogène implique une possible déstabilisation des cadres génériques, comme nous l'avons vu notamment dans Vathek, dans lequel Beckford procède par exacerbation et renversement de l'écriture gothique, et dans Hartley House, Calcutta, qui est comme un défi lancé par le sentimentalisme «véritable» des Indiens aux faux-semblants du sentimentalisme anglais. Les lettres orientales forcent les limites du canon poétique pour ouvrir à de nouvelles expériences esthétiques. Samuel Johnson écrit dans son journal The Adventurer : "our first concession is abundantly rewarded by the new scenes to which we are admitted, and the unbounded prospect that is thrown before us ».

Ce n'est qu'à la fin du XVIIIe siècle et grâce au travail de traduction et d'édition critique de textes persans et arabes par les orientalistes britanniques, tel Sir William Jones, qu'un rapport «normalisé » à la poésie orientale apparait. Ces érudits, employés à 
Calcutta par la Compagnie des Indes Orientales, s'attachent en effet à signaler et corriger les préjugés véhiculés notamment au sujet du pathos ou de la vigueur du verbe oriental. Néanmoins, ils se penchent en même temps sur un nouveau corpus, notamment le Baghavad Gita, des extraits des Upanishad, ou encore la pièce en sanscrit Sakuntala, qui, une fois traduits, serviront de vivier aux poètes et auteurs romantiques.

Claire GALLIEN

Université Paris Sorbonne

\section{OUVRAGES CITÉS}

ADDISON, Joseph. «Guardian 86 (June 19, 1713) ». The Guardian. Ed. John Calhoun Stephens. Lexington, KY : UP of Kentucky, 1982.

— . «Spectator 405 (June 14, 1712)». The Spectator. Ed. Donald F Bond. Vol. 3. Oxford : Clarendon P, 1965.

— . «Spectator 421 (July 3, 1712) ». The Spectator. Ed. Donald F Bond. Vol. 3. Oxford : Clarendon P, 1965.

- . «Spectator 512 (October 17, 1712) ». The Spectator. Ed. Donald F Bond. Vol. 4. Oxford : Clarendon P, 1965.

ARAVAMUDAN, Srinivas. "In the Wake of the Novel: The Oriental Tale as National Allegory ». Novel: A Forum on Fiction 33-1 (Autumn 1999) : 5-31.

Aristote. Poétique. Ed. Michel Magnien. Paris : Le livre de poche, 1995.

— . Rhétorique. Ed. Pierre Chiron. Paris : GF Flammarion, 2007.

BALlaster, Ros. "Narrative Transmigrations: The Oriental Tale and the Novel in Eighteenth-Century Britain ». A Companion to the Eighteenth-Century English Novel and Culture. Eds. Paula R. Backscheider and Catherine Ingrassia. Oxford : Blackwell, 2005.

Beattie, James. «On Fable and Romance». Dissertations Moral and Critical. Vol. 2. Dublin, 1783.

BECKFORD, William. An Arabian Tale, from an Unpublished Manuscript : With Notes Critical and Explanatory. London, 1786.

BHABHA, Homi. The Location of Culture. London : Routledge, 1994. 
BuDGELL, Eustace «Spectator 578 (August 9, 1714) ». The Spectator. Ed. Donald F. Bond. Vol. 4. Oxford : Clarendon P, 1965.

CANNON, Garland. «Sir William Jones and Literary Orientalism ». Oriental Prospects : Western Literature and the Lure of the East. Eds. Cedric Barfoot and Theo D'haen. Amsterdam: Rodopi, 1998.

—, «Sir William Jones and the New Pluralism over Languages and Cultures ». The Yearbook of English Studies 28 (1998) : 128-43.

Coste, Didier. «Rewriting, Literariness, Literary History». La Revue LISA/LISA e-journal II-5 (2004): 8-25. 30 mai 2010 $<$ http://lisa.revues.org/index2893.html >.

Defoe, Daniel. Preface. A Continuation of Letters Written by a Turkish Spy at Paris. London, 1718.

DE Sola PINTO, V. «Sir William Jones and English Literature». Bulletin of the School of Oriental and African Studies 11-4 (1946) : 686-94.

DodSON, Michael S. «Translating Science, Translating Empire : The Power of Language in Colonial North India ». Comparative Studies in Society and History 47.4 (Oct. 2005) : 809-35.

FESTA, Lynn. Sentimental Figures of Empire in Eighteenth-Century Britain and France. Baltimore, MD: The Johns Hopkins UP, 2006.

GibBES, Phebe. Hartly House, Calcutta. 1789. Ed. Michael J. Franklin. Oxford : Oxford UP, 2007.

Harvey, A. D. English Poetry in a Changing Society, 1780-1825. London : Allison and Busby, 1980.

HOLE, Richard. Remarks on the Arabian Nights' Entertainments. London, 1797.

HumE, David. «Of Eloquence». The Essays Moral, Political and Literary. Vol. 2. Edinburgh, 1741.

JoHnSON, Samuel. «The Adventurer 4 (Saturday, Nov. 18, 1752)». The Yale Edition of Works of Samuel Johnson. Ed. W. J. Bate. Vol. 2. New Haven: Yale UP, 1963.

JONES, Sir William. «Essay I. On the Poetry of the Eastern Nations ». Poems Consisting Chiefly of Translations from the Asiatick Languages. Oxford, 1772.

— . «Essay II. On the Arts Commonly Called Imitative». Poems Consisting Chiefly of Translations from the Asiatick Languages. Oxford, 1772. 
— . «A Hymn to Camdeo ». The Asiatick Miscellany. Ed. Francis Gladwin. Calcutta ; London, 1787.

— . «On the Musical Modes ». Asiatic Researches. Vol. 3. London, 1799.

LANNERING, Jan. Studies in the Prose of Joseph Addison. Cambridge, MA : Harvard UP, 1951.

LOWTH, Robert. Lectures on the Sacred Poetry of the Hebrews. Vol. 1. London, 1787.

Griffiths, R., ed. «Article VIII. A Discourse on the Institution of a Society for the Enquiring into [...] the Literature of Asia [...]». The Monthly Review for November, 1784. Vol. 71. London, 1785.

Moser, Joseph. Preface. The Hermit of Caucasus. An Oriental Romance. Vol. 1. London, 1796.

Revauger, Cécile. "Le Conte oriental à l'épreuve des Lumières en Angleterre ». Féeries 2 (2004-05): 193-208. 30 mai 2010 $<\mathrm{http} / / /$ feeries.revues.org/index115.html >.

REEVE, Clara. The Progress of Romance. Vol. 2. Colchester, 1785.

RICHARDSON, John. "A Dissertation on the Languages, Literature and Manners of Eastern Nations ». A Dictionary, Persian, Arabic and English. Vol. 1. Oxford, 1777-80.

SAID, Edward. Orientalism. 1978. Harmondsworth : Penguin Books, 2003.

WARTON, Joseph. Essay on the Writings and Genius of Pope. Vol. 1. London, 1782.

— . «Advertisement ». Odes on Various Subjects. London, 1746.

WeITZMAN, Arthur J. « More Light on Rasselas. The Background of the Egyptian Episodes ». Philological Quarterly 48 (Jan. 1969) : 42-58. 